\title{
Constitutive and Inducible Expression of Invasion- related Factors in PC-3 Prostate Cancer Cells
}

ORIGINAL

ARTICLE

\author{
Young Sun Hwang ${ }^{1}$, Paul F. Lindholm ${ }^{2}$ \\ ${ }^{1}$ Department of Dental Hygiene, College of Health Science, Eulji University, Seongnam, Korea, ${ }^{2}$ Department of Pathology, Northwestern University \\ Feinberg School of Medicine, Chicago, IL, USA
}

\begin{abstract}
Background: Tumor growth and invasion are interconnected with the tumor microenvironment. Overexpression of genes that regulate cancer cell invasion by growth factors, cytokines, and lipid factors can affect cancer aggressiveness. A comparative gene expression analysis between highly invasive and low invasive cells revealed that various genes are differentially expressed in association with invasive potential. In this study, we selected variant PC-3 prostate cancer cell sublines and discovered critical molecules that contributed to their invasive potential.

Methods: The high invasive and low invasive variant PC-3 cell sublines were obtained by serial selection following Matrigel-coated Transwell invasion and were characterized by Transwell invasion, luciferase reporter assay, and Rhotekin pull-down assay. Lysophosphatidic acid (LPA) was added to the cultures to observe the response to this extracellular stimulus. The essential molecules related with cancer invasiveness were detected with Northern blotting, quantitative reverse transcription-polymerase chain reaction, and cDNA microarray. Results: Highly invasive PC-3 cells showed higher nuclear factor kappa B (NF-kB), activator protein 1 (AP-1) and RhoA activities than of low invasive PC-3 cells. LPA promoted cancer invasion through NF- $\mathrm{kB}, \mathrm{AP}-1$, and RhoA activities. Thrombospondin-1, interleukin-8, kallikrein 6, matrix metalloproteinase-1, and tissue factor were overexpressed in the highly invasive PC-3 variant cells and further upregulated by LPA stimulation.

Conclusions: The results suggest that the target molecules are involved in invasiveness of prostate cancer. These molecules may have clinical value for anti-invasion therapy by serving as biomarkers for the prediction of aggressive cancers and the detection of pharmacological inhibitors.
\end{abstract}

(J Cancer Prev 2015;20:121-128)

Key Words: Prostate neoplasms, NF-kappa B, RhoA, Lysophosphatidic acid, Microarray

\section{INTRODUCTION}

Tumor dissemination is more likely to occur in cases of invasive cancer. Invasion of cells into surrounding tissue and the destruction of normal tissue architecture are hallmarks of malignant tumors. Primary cancer cells that lose the integrity of intercellular junctions gain invasive characteristics. Thus, defects in expression or structure of several components of the epithelial adherent junctions (e.g., E-cadherin, alpha-catenin) can occur, leading to migratory and invasive properties. ${ }^{1}$ Growing evidence shows that tumor growth and metastasis are intimately associated with the tumor microenvironment, including growth factors, cytokines, and lipid factors. ${ }^{2}$ Carcinomas are malignant neoplasms derived from epithelial cells surrounded by stroma that interacts with cancer cells to modulate cell growth, migration, invasion and tissue-specific gene expression. Therefore, crosstalk with the stroma could impact the aggressive response of cancer cells, and has emerged as a latent target for new anti-cancer drug development. In addition, understanding the cellular and molecular processes underlying cancer cell invasion will help develop reliable diagnostic tools to predict the invasive potential of cancer as well as molecular targets for cancer therapy.

Received May 15, 2015, Revised June 1, 2015, Accepted June 2, 2015

Correspondence to: Paul F. Lindholm

Department of Pathology, Northwestern University Feinberg School of Medicine, 303 E Chicago Ave, Chicago, IL 60611, USA

Tel: +1-312-926-8483, Fax: +1-312-503-8249, E-mail: p-lindholm@northwestern.edu, ORCID: Paul F. Lindholm, http://orcid.org/0000-0003-2498-6372

Copyright (C) 2015 Korean Society of Cancer Prevention

(c) This is an Open Access article distributed under the terms of the Creative Commons Attribution Non-Commercial License (http://creativecommons.org/licenses/by-nc/4.0) which permits unrestricted non-commercial use, distribution, and reproduction in any medium, provided the original work is properly cited. 
Prostate cancer is a great public health concern and a disease of older men, as the prostate cancer rate increases significantly in men $\geq 40$ years. About two-thirds of all prostate cancers occur in men $\geq 65$ years. ${ }^{3,4}$ The incidence and mortality of prostate cancer in most native Asian populations has been increasing but are approximately one-third lower in corresponding Asian-American cohorts, which is less than the rates in other corresponding American cohorts. ${ }^{5}$ However, prostate cancer is a leading cause of cancer death in men. Mortality results from cancer invasion and metastasis; therefore, it is important to understand the molecular mechanisms by which prostate cancer invades and metastasizes to identify more definitive prognostic tools to predict invasive potential and molecular targets for cancer therapy.

To address this issue, we derived high and low invasion variants of PC-3 human prostate cancer cells by serial selection using Matrigel reconstituted basement membranes and analyzed differences in gene expression. PC-3 cells were stimulated with lysophosphatidic acid (LPA) to explore molecules that increase invasion activity. LPA is present at elevated levels in ascitic fluid and plasma from patients with ovarian, endometrial and cervical cancers and stimulates tumor growth and osteolytic bone metastases. $^{6-8}$ Accordingly, our results reveal that the highly invasive cancer express increased pro-angiogenic factors; extracellular matrix proteases and invasion/motility-promoting factors which may drive the cancer progression towards a more aggressive phenotype. This study discovered several prostate cancer invasionassociated factors that were further increased by lysophosphatidic acid treatment, leading to high levels of prostate cancer cell invasion.

\section{MATERIALS AND METHODS}

\section{Materials}

RPMI 1640, Dulbecco's modified Eagle's medium (DMEM), fetal bovine serum (FBS), antibiotics $(100 \mathrm{U} / \mathrm{mL}$ penicillin $\mathrm{G}, 100$ $\mu \mathrm{g} / \mathrm{mL}$ streptomycin sulfate and $2 \mathrm{mM}$ L-glutamine), phosphatebuffered saline, $0.25 \%$ trypsin-ethylenediaminetetraacetic acid (EDTA) and serum- and antibiotics-free Opti-MEM were purchased from Gibco BRL Co. (Rockville, MD, USA). LPA was purchased from Enzo Life Sciences (Plymouth Meeting, PA, USA). Double-stranded oligonucleotides containing the nuclear factor kappa B (NF-кB) (5'-AGTTGAGGGGACTTTCCCAGGC-3') or activator protein 1 (AP-1) (5'-CGCTTGATGAGTCAGCCGGAA-3') consensus sequences were purchased from Gibco. A T4 polynucleotide kinase Nick column and poly (dI-dC/ dI-dC) were purchased from Amersham Pharmacia Biotechnology (Piscataway, NJ, USA).
DMSO and all other chemicals were purchased from Sigma-Aldrich (St. Louis, MO, USA). The RhoA antibody was purchased from Santa Cruz Biotechnology (Santa Cruz Biotechnology, Santa Cruz, CA, USA) and horseradish peroxidase-conjugated secondary antibodies was purchased from Amersham Pharmacia Biotechnology.

\section{Cell culture}

PC-3 and DU145 human prostate cancer cells were cultured in RPMI 1640 medium supplemented with 10\% FBS and antibiotics in a humidified atmosphere of $5 \% \mathrm{CO}_{2}$ at $37^{\circ} \mathrm{C}$. MDA-MB-231 and BT549 human breast cancer cells were cultured in DMEM supplemented with $10 \% \mathrm{FBS}$. The high invasive and low invasive variant PC-3 cell sublines, PC-3 High and PC-3 Low, respectively, were obtained by serial selection through Matrigel-coated Transwell invasion.

\section{Invasion assay}

Invasive activity was estimated using $\left[{ }^{3} \mathrm{H}\right]$ thymidine-labeled cells, as previously described. ${ }^{9}$ The upper surfaces of $8-\mu \mathrm{m}$ pore size polycarbonate nucleopore filter inserts in a 24-well Transwell chamber (Corning Costar, Cambridge, MA, USA) were coated with Matrigel (30 $\mu \mathrm{g} /$ well; Becton Dickinson, Lincoln Park, NJ, USA). The $\left[{ }^{3} \mathrm{H}\right]$ thymidine-labeled cells $\left(5 \times 10^{4}\right.$ cells $)$ were seeded into the upper part of the Matrigel-coated filters, and medium was added to the lower part. The radioactivity of the cells that invaded through the Matrigel into the lower part of the chamber was counted using a LS6500 liquid scintillation counter with a liquid scintillation cocktail (Beckman Coulter, Fullerton, CA, USA). Results are expressed as changes in invasion relative to controls.

\section{Luciferase assay}

The luciferase reporter assay was performed as described previously. ${ }^{10}$ Upon reaching $70 \%$ to $80 \%$ confluence, the cells were cotransfected with $0.5 \mu \mathrm{g}$ pSV- $\beta$-galactosidase and $1 \mu \mathrm{g}$ of pTAL-Luc vector, pNF-kB-Luc, or pAP-1-Luc reporter plasmid (Clontech, Palo Alto, CA, USA) for 8 hours in serum- and antibiotics-free OptiMEM with the Lipofectamine 2000 reagent. The cells were incubated in complete medium for an additional further 48 hours at $37^{\circ} \mathrm{C}$. Cellular protein was harvested 48 hours post-transfection with the luciferase reporter vector into the high and low invasive PC-3 cells, and reporter activities were quantified by the luciferase assay. Luciferase and $\beta$-galactosidase activities were assayed using a microplate spectrofluorometer according to the manufacturer's protocol (Promega, Madison, WI, USA). Luciferase activity in cell lysate was normalized to $\beta$-galactosidase activity 
and expressed as the mean of three independent experiments.

\section{Electrophoretic mobility shift assay}

The electrophoretic mobility shift assay (EMSA) was performed using a DNA-protein binding detection kit (Promega), according to the manufacturer's protocol. Double-stranded oligonucleotides containing the NF-KB or AP-1 consensus sequences were end-labeled with Klenow $\left[\gamma^{32} \mathrm{P}\right]$ adenosine triphosphate $(3,000 \mathrm{Ci} / \mathrm{mmol})$ using $\mathrm{T} 4$ polynucleotide kinase and purified with a NICK column (Amersham Pharmacia Biotechnology). The eluted solutions were used as EMSA probes. Nuclear extracts (10 $\mu \mathrm{g})$ were incubated with binding buffer (10 mM Tris- $\mathrm{HCl}$ [pH 7.5], $100 \mathrm{mM} \mathrm{NaCl}, 1 \mathrm{mM}$ DTT, $1 \mathrm{mM}$ EDTA, 4\% [v/v] glycerol, and 1 $\mu \mathrm{g} / \mu \mathrm{L}$ poly $\mathrm{dI}-\mathrm{dC}$ ) for 10 minutes at room temperature and then treated with 0.5 pmol labeled probe for 20 minutes. The DNA-protein complex was separated on a $6 \%$ polyacrylamide gel in $0.5 \times$ Tris-Borate-EDTA buffer at $10 \mathrm{~V}$ for 3 hours. The gels were dried and exposed to Kodak-XAR Film (Rochester, NY, USA).

\section{Rhotekin pull-down assay}

RhoA activity was measured using the glutathione S-transferaseRhotekin pull down assay according to the manufacturer's protocol (Upstate Cell Signaling, Charlottesville, VA, USA). Rhotekinbound RhoA (guanosine triphosphate [GTP] bound active form) was measured by Western blot with anti-RhoA antibody.

\section{Northern blot}

Total RNA was extracted and Northern blot hybridization were performed as described previously. ${ }^{11}$ The cDNA were prepared from the IMAGE human (Invitrogen, Carlsbad, CA, USA); Thrombospondin-1 (TSP-1), \#Clone ID; 2262742, interleukin-8 (IL-8), \#Clone ID; 5760258, kallikrein 6 (KLK6); \#Clone ID; 5193085. matrix metalloproteinase-1 (MMP-1), 6722233, tissue factor (TF), \#Clone ID; 4752970. Each cDNA probe was radiolabed with $\left[\alpha_{-}^{32} \mathrm{P}\right]$ deoxyribonucleoside triphosphate using the randompriming technique and the Rediprime labeling system (Amersham Pharmacia Biotechnology). The probed nylon membranes were exposed to radiographic film.

\section{8. cDNA microarray analysis}

Total RNA from the variant PC-3 cell sublines was examined by microarray analysis with an Array gene chip containing 60k probes (Affymetrix, Santa Clara, CA, USA) according to the manufacturer's instructions.

\section{Quantitative reverse transcription-polymerase chain reaction}

Total RNA was isolated using TRIzol reagent, and RNA concentration was measured spectrophotometrically at an optical density of $260 \mathrm{~nm}$. Quantitative reverse transcription-polymerase chain reaction (RT-PCR) was performed using the GeneAmp RNA PCR Kit (Applied Biosystems, Foster City, CA, USA) and the ABI 7500 real time PCR system (Applied Biosystems) with $2 \mu \mathrm{L}$ complementary DNA in a total reaction volume of $20 \mu \mathrm{L}$ using the SYBR Green PCR mix (Eurogentec, Seraing, Belgium). Glyceraldehyde-3-phosphate dehydrogenase was used as the housekeeping gene for normalization. Primer sequences are given in Table 1 . Specificity of the products was confirmed by melting curve analysis.

\section{Statistics}

The statistical analysis was conducted using InStat ${ }^{\mathrm{TM}}$ statistical software (GraphPad Software Inc., San Diego, CA, USA), and the results are expressed as mean \pm standard error. Repeated-

Table 1. Primer sequences and annealing temperatures for the reverse transcription-polymerase

\begin{tabular}{|c|c|c|}
\hline Target gene & Primer sequence & Annealing temp $\left({ }^{\circ} \mathrm{C}\right)$ \\
\hline \multirow[t]{2}{*}{ Thrombospondin-1 } & Sense:5'-GTGTTTGACATCTTTGAACTC-3' & 58 \\
\hline & Antisense:5'-CCAAAGACAAACCTCACATTC-3' & \\
\hline \multirow[t]{2}{*}{ Interleukin-8 } & Sense:5'-ATGACTTCCAAGCTGGCCGT-3' & 55 \\
\hline & Antisense; 5'-ССТСТTCAAAАACTТСТССАСАСС-3' & \\
\hline \multirow[t]{2}{*}{ Kallikrein 6} & Sense;5'-AGAAGCATCTGGGGACAGAACCAG-3' & 61 \\
\hline & Antisense:5'-CTGCAGCAATCAGACTCAGCACCAC-3' & \\
\hline \multirow[t]{2}{*}{ MMP-1 } & Sense:5'-AGCTAGCTCAGGATGACATTGATG-3' & 60 \\
\hline & Antisense:5'-GCCGATGGGCTGGACAG-3' & \\
\hline \multirow[t]{2}{*}{ Tissue factor } & Sense:5'-TCCCGAACAGTTAACCGGAA-3' & 60 \\
\hline & Antisense:5'-GACCACAAATACCACAGCTCCA-3' & \\
\hline \multirow[t]{2}{*}{ GAPDH } & Sense:5'-ATCССTCCAAAATCAAGTGGG-3' & 60 \\
\hline & Antisense; 5'-TGAAGACGCCAGTGGACTCC-3' & \\
\hline
\end{tabular}

temp, temperature; MMP-1, matrix metalloproteinase-1; GAPDH, glyceraldehyde-3-phosphate dehydrogenase. 
measures Student's paired and unpaired $t$-tests were used to identify differences between the groups. $P$-values $<0.05$ were considered significant.

\section{RESULTS}

1. Highly invasive PC-3 cells show increased nuclear factor kappa B, AP-1 and RhoA activities

The highly invasive PC-3 cells showed relatively higher Transwell invasion activity than that of low invasive PC-3 cells (Fig. 1A). Activation of NF-KB and AP-1 was higher in the highly invasive PC-3 High cells on the luciferase reporter assay than that in the low invasive PC-3 Low cells (Fig. 1B). The EMSA showed similar results (Fig. 1C). RhoGTPases are overexpressed in several aggressive cancers ${ }^{12}$ and RhoA stimulates expression of NF- $\kappa \mathrm{B}-$ regulated, inflammation modifying genes, including TF, MMP-9, and urokinase type plasminogen activator, which are related to cancer invasion and metastasis. The Rhotekin pull-down assay was performed to determine if RhoA was also activated in the highly invasive PC-3 cells. As shown Figure 1D, significantly increased RhoA activity was observed in the highly invasive PC-3 High cells.

\section{Lysophosphatidic acid stimulates cancer invasion, nuclear factor kappa B, activator protein 1 and RhoA activities}

Reciprocal crosstalk between tumor cells and their adjacent microenvironment is crucial during tumor growth and metastasis. ${ }^{2}$ The high and low invasive PC-3 cells were stimulated with LPA, a bioactive phospholipid present at high levels in ascites fluid and plasma of patients with cancer. LPA has been shown to stimulate cancer cell invasiveness through increasing RhoA GTPase activity. ${ }^{6-8}$ Under serum-free conditions, LPA significantly increased Transwell invasion of both the high and low invasive PC-3 cells (Fig. 2A). The LPA-stimulated increases invasion was also observed in other cancer cell lines, although there were differences in the response to LPA. NF-KB and AP-1 activities also increased in response to LPA under serum-free conditions (Fig. 2B). LPA stimulated NF- $\kappa B$ DNA binding activity to the maximum level at 1 hour and increased AP-1 DNA binding activity at 4 hours.
A

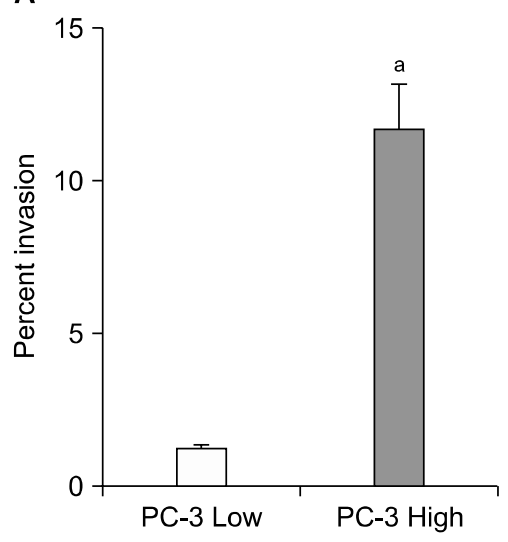

C

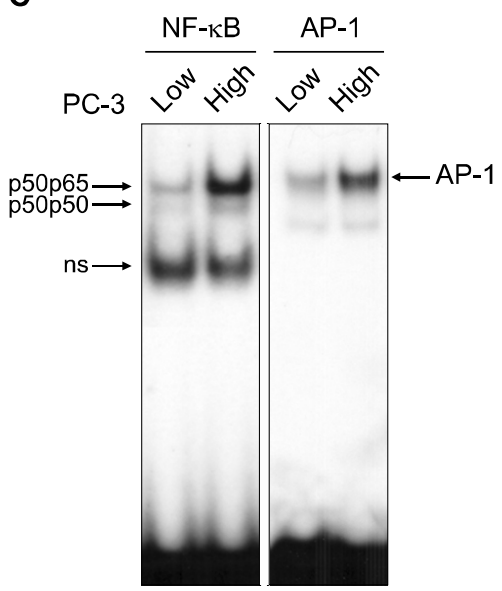

B

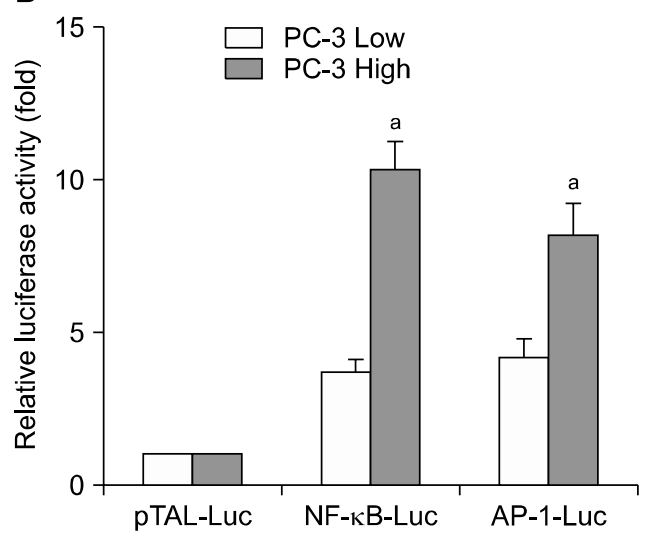

D

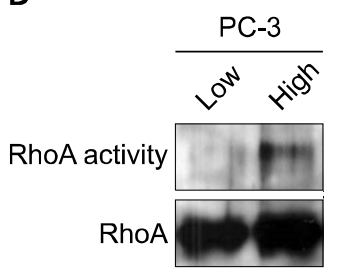

Figure 1. High nuclear factor kappa $\mathrm{B}$ (NF-KB), activator protein-1 (AP-1), and RhoA activities in highly invasive PC-3 cells. (A) In vitro invasion through Matrigel-coated Transwells by the variant PC-3 cell sublines in serum. Data are mean \pm standard error of the mean (SEM) of five independent experiments $\left({ }^{\mathrm{a}} P<0.001\right.$ vs. PC-3 Low). (B) Prostate cancer cell NF-KB and AP-1 luciferase reporter activity showing increased NF-KB and AP-1 activity in PC-3 High invasive prostate cancer cells. Data are mean \pm SEM of five independent experiments ( ${ }^{a} P<0.05$ vs. PC-3 Low in the same group). (C) NF-KB and AP-1 DNA binding activities in the high and low invasive PC-3 cells were determined by the electrophoretic motility shift assay. NF- $\mathrm{KB}$ and AP-1 DNA binding complexes are designated by arrows. ns, non-specific band. (D) RhoA activities in the variant PC-3 cell sublines were determined using the Rhotekin pull-down assay. 
A

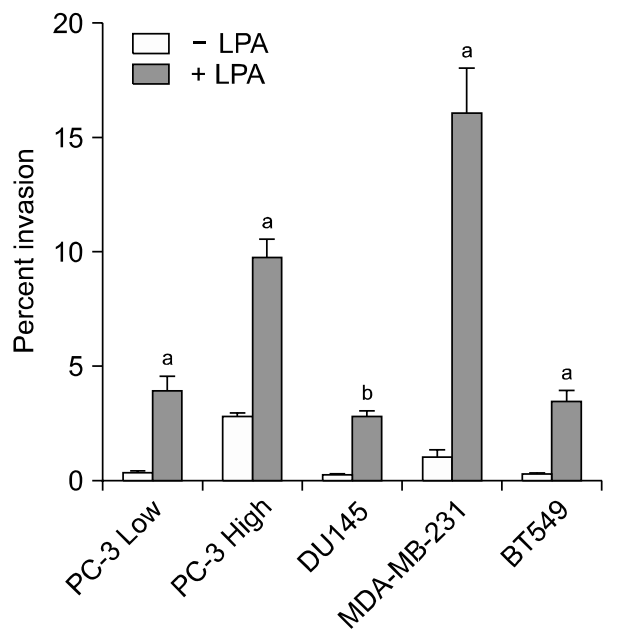

B

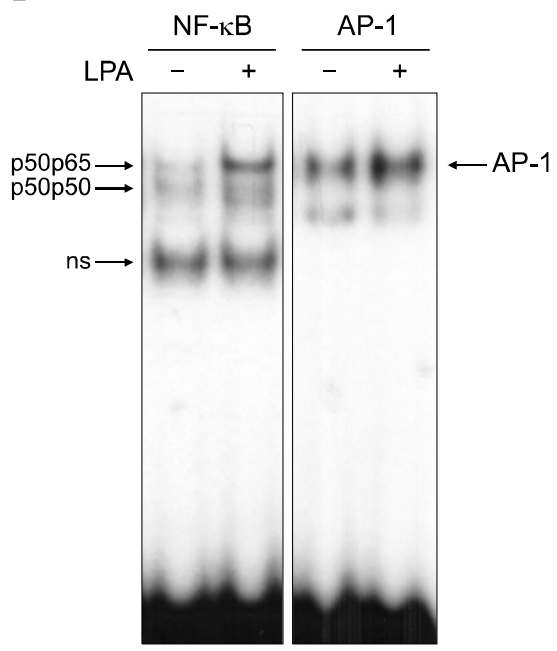

Figure 2. Lysophosphatidic acid (LPA) stimulates cancer invasion and nuclear factor kappa B (NF- $\mathrm{KB}$ ), activator protein-1 (AP-1), and RhoA activities. (A) In vitro invasion assay was performed with the variant PC-3 cell sublines (PC-3 Low and High), DU145 (prostate cancer cells), MDA-MB-231 (breast cancer cells), and BT549 (breast cancer cells) under serum-free conditions. LPA $(1 \mu \mathrm{M})$ was added to the lower Transwell chambers. Data are mean \pm standard error of the mean of three independent experiments ${ }^{(a} P<0.001,{ }^{\mathrm{b}} P<0.05$ vs. without LPA control). (B) NF-KB and AP-1 DNA binding activities in LPA- treated PC-3 cells under serum-free conditions. ns, non-specific band. Results are representative of three independent experiments. (C) RhoA activity of LPA-stimulated PC-3 cells. A western blot was performed after an LPA time course to detect maximum RhoA activity through RhoA binding to glutathione S-transferase-Rhotekin beads.

Table 2. cDNA microarray analysis

\begin{tabular}{lccl}
\hline \multirow{2}{*}{ Target gene } & \multicolumn{2}{c}{ PC-3 } & \\
\cline { 2 - 3 } & $\begin{array}{c}\text { High signal- } \\
\text { low signal }\end{array}$ & High/Low & \\
\hline Thrombospondin-1 & $4,412.1$ & 40.74865 & NM_003246.1 \\
Interleukin-8 & $2,0642.6$ & 7.141255 & AF043337.1 \\
Kallikrein 6 & $6,929.2$ & 12.3056 & NM_002774.1 \\
MMP-1 & $1,400.3$ & 6.144379 & NM_002421.2 \\
Tissue factor & $1,717.6$ & 26.0379 & NM_015366.1 \\
GAPDH & 614 & 1.00829 & M33197.1 \\
\hline
\end{tabular}

MMP-1, matrix metalloproteinase-1; GAPDH, glyceraldehyde-3-phosphate dehydrogenase.

LPA rapidly induced RhoA activity, and maximum Rhotekin-bound RhoA levels occurred within 4-6 min and returned to baseline by 10 minutes (Fig. 2C).

\section{Target molecules involved in prostate cancer invasiveness}

Total RNA from the variant PC-3 cell sublines was examined by microarray analysis to verify changes in gene expression. As shown Table 2, the level of TSP-1, IL-8, KLK6, MMP-1, and TF were significantly different between the high and low invasive PC-3 cells. The PC-3 cells were treated with LPA and a Northern blot was performed to demonstrate whether expression of these genes could be induced by this stimulus. LPA induced the

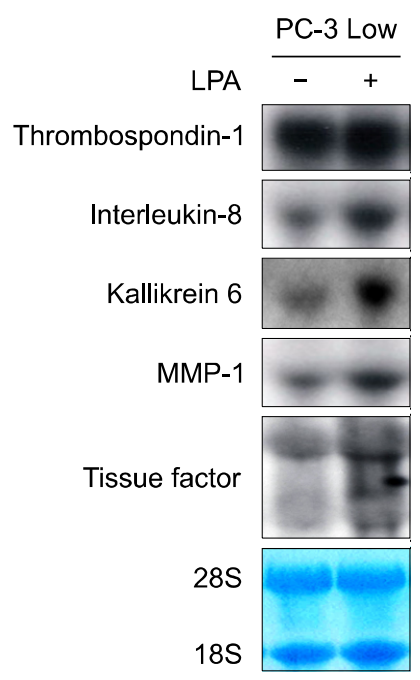

Figure 3. Lysophosphatidic acid (LPA)-stimulated expression of selected genes. Northern blot analysis was performed to determine the effect of LPA on the mRNA expression levels of several genes in the low invasive PC-3 prostate cancer cells. LPA was treated for 8 hours under serum-free condition. $18 \mathrm{~S}$ and $28 \mathrm{~S}$ are loading controls. MMP-1, matrix metalloproteinase-1.

expression of these genes under serum-free conditions, although there were differences in the degree of response (Fig. 3). The same changes in gene expression were observed by the RT-PCR analysis with specific probes (Table 3), although the fold-change in expression was not always the same using these two different 
Table 3. Lysophosphatidic acid (LPA)-stimulated genes expression in the low invasive PC-3 prostate cancer cells

\begin{tabular}{lcr}
\hline \multirow{2}{*}{ Target gene } & \multicolumn{2}{c}{ PC-3 Low } \\
\cline { 2 - 3 } & \multicolumn{1}{c}{ LPA } & \multicolumn{1}{c}{+ LPA } \\
\hline Thrombospondin-1 & $1.02 \pm 0.33$ & $5.89 \pm 1.58^{\mathrm{a}}$ \\
Interleukin-8 & $1.00 \pm 0.21$ & $24.37 \pm 0.06^{\mathrm{a}}$ \\
Kallikrein 6 & $1.02 \pm 0.10$ & $33.97 \pm 4.18^{\mathrm{a}}$ \\
MMP-1 & $1.01 \pm 0.07$ & $8.91 \pm 1.29^{\mathrm{a}}$ \\
Tissue factor & $1.05 \pm 0.48$ & $12.12 \pm 8.31^{\mathrm{b}}$ \\
\hline
\end{tabular}

MMP-1, matrix metalloproteinase-1. ${ }^{\mathrm{a}} P<0.01,{ }^{\mathrm{b}} P<0.05$.

analytical methods. Expression of the differentially regulated genes in the microarray results with the variant PC-3 cell sublines were in direct agreement with the LPA-induced results.

\section{DISCUSSION}

Molecular analyses of cancer cells in various stages of progression have revealed that alterations in tumor suppressor genes and oncogenes accumulate during tumor progression and correlate with the clinical aggressiveness of the cancer. ${ }^{13}$ Moreover, these genetic alterations are associated with the cancer cell metastatic phenotype. ${ }^{13}$ Prostate cancer malignancy is determined by its tendency to metastasize to other parts of the body, most commonly the bones, lymph nodes, and possibly the rectum, bladder, and lower ureters after local progression. Cancer cells must undergo phenotypic changes associated with aggressiveness to develop invasive characteristics. However, despite a steady effort, the identification of target molecules involved in increased invasiveness has been limited. We established high and low invasion variants of PC-3 prostate cancer cells using the in vitro serial selection in a Transwell invasion system. These highly invasive PC-3 High cells showed higher NF-KB, AP-1 and RhoA activities than those of low invasive PC-3 Low cells. These molecules are involved in initiating tumors ${ }^{14}$ but, more importantly, they have also been associated with cancer progression by promoting angiogenesis, ${ }^{15}$ motility, ${ }^{16}$ blood vessel and lymphatic intravasation, ${ }^{17}$ immunosurveillance evasion, ${ }^{18}$ invasion, and metastasis.

In this study, LPA exerted an activating effect on PC-3 cancer invasiveness through increasing NF-KB, AP-1, and RhoA activities. LPA is a naturally occurring phospholipid that is detected in plasma at concentrations of $0.1 \mu \mathrm{M}$ but reaches micromolar levels in serum after platelet aggregation. However, LPA is present at elevated levels in ascites fluid (up to $80 \mu \mathrm{M}$ ) and plasma from patients with ovarian, endometrial, and cervical cancers. ${ }^{6}$ Many cellular effects of LPA have been reported, including cell proliferation, ${ }^{19}$ cell survival and drug resistance, ${ }^{20.21}$ cell motility, and invasion. ${ }^{22,23}$ Previous studies has demonstrated that endogenously produced LPA is closely associated with bone metastases. Metastatic progression of breast cancer to bone is markedly impaired by LPA receptor $\left(\mathrm{LPA}_{1}\right)$ silencing or pharmacological blockade of $\mathrm{LPA}_{1}$ activity using Ki16425 in a mouse hind limbs model. ${ }^{24}$ In addition, autotaxin, which catalyzes production of the majority of LPA from lysophosphatidylcholine in vivo, promotes cancer invasion via the purigenic cluster of G-proteincoupled receptors including $\mathrm{LPA}_{4}$. Depleting $\mathrm{LPA}_{4}$ results in significantly less lung metastasis in a HT1080 human fibrosarcoma cell line through mouse tail vein injection. ${ }^{25}$ LPA also enhances differentiation of osteoclast precursors and regulates the morphology, resorptive activity, and survival of mature osteoclasts. ${ }^{26-28}$ Therefore, LPA, LPA signaling, and LPA target molecules may be diagnostic and therapeutic targets to treat patients with prostate cancer.

Prostate cancer is the most commonly diagnosed malignancy and the second leading cause of cancer-related death in men. Currently, the effective test that can confirm the diagnosis of prostate cancer is combined determination of the clinical stage of the primary tumor (based on digital rectal examination, DRE) and serum level of prostate-specific antigen (PSA), followed by immunohistological analysis of a prostate biopsy. However, diagnosis through palpation of the prostate by DRE misses nearly $25 \%$ to $50 \%$ of early tumors and commonly understages those tumors that are found. Although screening for PSA has led to earlier detection of prostate cancer and a decrease in the number of patients with advanced disease, ${ }^{29}$ the specificity and sensitivity of such screening is only average. ${ }^{30.31}$ In fact, $25 \%$ of men that have palpable cancers present with normal PSA levels, ${ }^{32}$ and $20 \%$ of prostate cancers with aggressive features are found in men with normal levels of PSA. ${ }^{33}$ In addition, since prostate cancer is a multi-focal process with tumor cells infiltrating into the tissue between benign ducts and acini, ${ }^{34}$ the distribution of tumors within the prostate is not uniform causing difficulty in determining the number of and appropriate sites for biopsy cores to be taken and thus resulting in sampling error. These facts, combined with the knowledge that cancer invasion and metastasis are essential steps leading to patient morbidity and mortality, illustrate an urgent need to identify new molecular markers for prostate cancer invasion and metastasis. Hence, we verified expression of differentially regulated genes between highly invasive and low invasive PC-3 cell sublines using CDNA microarray. They might be associated with aggressiveness to develop 
invasive characteristics. TSP-1, IL-8, KLK6, MMP-1, and TF were expressed at significantly higher levels in highly invasive PC-3 High cells than in the low invasive PC-3 Low cells. These genes were also upregulated by LPA stimulation. Thus, anti- cancer therapies targeting specific genes controlling invasion of prostate cancer may be of benefit to treat prostate cancer. Serum IL-8 is elevated in men with prostate cancer and bone metastases, ${ }^{35}$ and IL-8 regulates tumorigenicity and metastases in androgenindependent prostate cancer. ${ }^{36}$ MMP-1 also plays an important role in the progression of prostate cancer during the invasive and metastatic stages. ${ }^{37}$ TSP-1 expression is associated with clinicopathological features and prognoses in many types of cancers. However, TSP-1 is a multi-functional protein, and its biological activities vary according to the specific tumor environment. Although TSP-1 may act as a promoter of prostate cancer, it expression and carcinogenic activities remain controversial. ${ }^{38-43}$ Particularly, expression of TF in prostate cancer is significantly correlated with a malignant phenotype. ${ }^{44} \mathrm{TF}$ expression is increased in aggressive malignant melanoma, pancreatic, colorectal, non-small cell lung, breast, and prostate carcinomas. ${ }^{45}$ Investigation in our group has shown that TF expression was positively correlated with prostate cancer invasion activity in several cancer cell lines and co-cultures with human monocyte lineage cells increased prostate cancer cell TF expression. ${ }^{46}$ The prostate cancer cell invasion depended on TF expression as invasion was inhibited by anti-TF neutralizing antibodies. Clinical prostate cancer epithelium also showed increased TF expression compared with benign prostate epithelium. Further studies are needed to investigate the effects of these target genes that are upregulated in the invasive cancer cells. These target factors may be important molecules for predicting the invasive and metastatic potential of prostate cancer as well as molecular therapeutic targets.

\section{ACKNOWLEDGMENTS}

This work was funded by the Department of Defense New Investigator Grant DAMD17-02-1-0162 and a Career Development Award from the National Cancer Institute Prostate S.P.O.R.E. P50 CA-090386 at Northwestern University Robert H. Lurie Comprehensive Cancer Center and by Basic Science Research Program through the National Research Foundation of Korea (NRF) funded by the Ministry of Education, Science and Technology (2012R1A1A2040564).

\section{CONFLICTS OF INTEREST}

No potential conflicts of interest were disclosed.

\section{REFERENCES}

1. Ottewell PD, O'Donnell L, Holen I. Molecular alterations that drive breast cancer metastasis to bone. Bonekey Rep 2015:4:643.

2. Sung SY, Hsieh CL, Wu D, Chung LW, Johnstone PA. Tumor microenvironment promotes cancer progression, metastasis, and therapeutic resistance. Curr Probl Cancer 2007;31:36-100.

3. Howlader N, Noone AM, Krapcho M, Neyman N, Aminou R, Waldron W, et al. SEER cancer statistics review, 1975-2008, Bethesda, MD, National Cancer Institute. http://seer.cancer.gov/ archive/csr/1975_2008/. Accessed 2011.

4. Wilt TJ, Ahmed HU. Prostate cancer screening and the management of clinically localized disease. BMJ 2013;346: $\{325$.

5. Ito K. Prostate cancer in Asian men. Nat Rev Urol 2014;11:197212.

6. Mills GB, Moolenaar WH. The emerging role of lysophosphatidic acid in cancer. Nat Rev Cancer 2003:3:582-91.

7. Boucharaba A, Serre CM, Grès S, Saulnier-Blache JS, Bordet JC, Guglielmi J, et al. Platelet-derived lysophosphatidic acid supports the progression of osteolytic bone metastases in breast cancer. J Clin Invest 2004:114:1714-25.

8. David M, Wannecq E, Descotes F, Jansen S, Deux B, Ribeiro J, et al. Cancer cell expression of autotaxin controls bone metastasis formation in mouse through lysophosphatidic acid-dependent activation of osteoclasts. PLoS One 2010;5:e9741.

9. Hwang YS, Xianglan Z, Park KK, Chung WY. Functional invadopodia formation through stabilization of the PDPN transcript by IMP-3 and cancer-stromal crosstalk for PDPN expression. Carcinogenesis 2012;33:2135-46.

10. Hwang YS, Park KK, Chung WY. Kalopanaxsaponin A inhibits the invasion of human oral squamous cell carcinoma by reducing metalloproteinase-9 mRNA stability and protein trafficking. Biol Pharm Bull 2012;35:289-300.

11. Baek MK, Park JS, Park JH, Kim MH, Kim HD, Bae WK, et al. Lithocholic acid upregulates UPAR and cell invasiveness via MAPK and AP-1 signaling in colon cancer cells. Cancer Lett 2010; 290:123-8

12. Sahai E, Marshall CJ. RHO-GTPases and cancer. Nat Rev Cancer 2002;2:133-42.

13. Yokota J. Tumor progression and metastasis. Carcinogenesis 2000;21:497-503.

14. Shen G, Jeong WS, Hu R, Kong AN. Regulation of Nrf2, NFkappaB, and AP-1 signaling pathways by chemopreventive agents. Antioxid Redox Signal 2005; 7:1648-63.

15. Stoltz RA, Abraham NG, Laniado-Schwartzman M. The role of NFkappaB in the angiogenic response of coronary microvessel endothelial cells. Proc Natl Acad Sci U S A 1996;93:2832-7.

16. Hodge JC, Bub J, Kaul S, Kajdacsy-Balla A, Lindholm PF. Requirement of RhoA activity for increased nuclear factor kappaB activity and PC-3 human prostate cancer cell invasion. Cancer Res 2003; 63:1359-64.

17. Vonach C, Viola K, Giessrigl B, Huttary N, Raab I, Kalt R, et al. $\mathrm{NF}-\mathrm{KB}$ mediates the $12(\mathrm{~S})$-HETE-induced endothelial to mesen- 
chymal transition of lymphendothelial cells during the intravasation of breast carcinoma cells. Br J Cancer 2011;105:263-71.

18. Hoesel B, Schmid JA. The complexity of NF-KB signaling in inflammation and cancer. Mol Cancer 2013;12:86.

19. Xu Y, Shen Z, Wiper DW, Wu M, Morton RE, Elson P, et al. Lysophosphatidic acid as a potential biomarker for ovarian and other gynecologic cancers. JAMA 1998;280:719-23.

20. Frankel A, Mills GB. Peptide and lipid growth factors decrease cis-diamminedichloroplatinum-induced cell death in human ovarian cancer cells. Clin Cancer Res 1996;2:1307-13.

21. Fang X, Schummer M, Mao M, Yu S, Tabassam FH, Swaby R, et al. Lysophosphatidic acid is a bioactive mediator in ovarian cancer. Biochim Biophys Acta 2002;1582:257-64.

22. Fishman DA, Liu Y, Ellerbroek SM, Stack MS. Lysophosphatidic acid promotes matrix metalloproteinase (MMP) activation and MMP-dependent invasion in ovarian cancer cells. Cancer Res 2001;61:3194-9.

23. Sawada K, Morishige K, Tahara M, Kawagishi R, Ikebuchi $Y$, Tasaka $\mathrm{K}$, et al. Alendronate inhibits lysophosphatidic acid-induced migration of human ovarian cancer cells by attenuating the activation of rho. Cancer Res 2002;62:6015-20.

24. Boucharaba A, Serre CM, Guglielmi J, Bordet JC, Clézardin P, Peyruchaud $\mathrm{O}$. The type 1 lysophosphatidic acid receptor is a target for therapy in bone metastases. Proc Natl Acad Sci U S A 2006; 103:9643-8.

25. Harper K, Arsenault D, Boulay-Jean S, Lauzier A, Lucien F, Dubois $\mathrm{CM}$. Autotaxin promotes cancer invasion via the lysophosphatidic acid receptor 4: participation of the cyclic AMP/EPAC/Rac1 signaling pathway in invadopodia formation. Cancer Res 2010;70: 4634-43.

26. Panupinthu N, Rogers JT, Zhao L, Solano-Flores LP, Possmayer F, Sims SM, et al. P2X7 receptors on osteoblasts couple to production of lysophosphatidic acid: a signaling axis promoting osteogenesis. J Cell Biol 2008;181:859-71.

27. Sims SM, Panupinthu N, Lapierre DM, Pereverzev A, Dixon SJ. Lysophosphatidic acid: a potential mediator of osteoblast-osteoclast signaling in bone. Biochim Biophys Acta 2013;1831:109-16.

28. Hwang YS, Ma GT, Park KK, Chung WY. Lysophosphatidic acid stimulates osteoclast fusion through OC-STAMP and P2X7 receptor signaling. J Bone Miner Metab 2014;32:110-22.

29. Barry MJ. Clinical practice. Prostate-specific-antigen testing for early diagnosis of prostate cancer. N Engl J Med 2001;344:1373-7.

30. Brawer MK. Prostate-specific antigen: current status. CA Cancer J Clin 1999;49:264-81.

31. Catalona WJ, Smith DS, Ornstein DK. Prostate cancer detection in men with serum PSA concentrations of 2.6 to $4.0 \mathrm{ng} / \mathrm{mL}$ and benign prostate examination: enhancement of specificity with free PSA measurements. JAMA 1997;277:1452-5.

32. Carroll P, Coley C, McLeod D, Schellhammer P, Sweat G, Wasson J, et al. Prostate-specific antigen best practice policy--part I: early detection and diagnosis of prostate cancer. Urology 2001;57:217-24.
33. Richie JP, Catalona WJ, Ahmann FR, Hudson MA, Scardino PT, Flanigan RC, et al. Effect of patient age on early detection of prostate cancer with serum prostate-specific antigen and digital rectal examination. Urology 1993;42:365-74.

34. Humphrey PA. Gleason grading and prognostic factors in carcinoma of the prostate. Mod Pathol 2004;17:292-306.

35. Lehrer S, Diamond EJ, Mamkine B, Stone NN, Stock RG. Serum interleukin-8 is elevated in men with prostate cancer and bone metastases. Technol Cancer Res Treat 2004:3:411.

36. Inoue K, Slaton JW, Eve BY, Kim SJ, Perrotte P, Balbay MD, et al. Interleukin 8 expression regulates tumorigenicity and metastases in androgen-independent prostate cancer. Clin Cancer Res 2000; 6:2104-19

37. Pulukuri SM, Rao JS. Matrix metalloproteinase-1 promotes prostate tumor growth and metastasis. Int J Oncol 2008;32:757-65.

38. Kaushal V, Mukunyadzi P, Siegel ER, Dennis RA, Johnson DE, Kohli M. Expression of tissue factor in prostate cancer correlates with malignant phenotype. Appl Immunohistochem Mol Morphol 2008;16:1-6.

39. Sutton CD, O'Byrne K, Goddard JC, Marshall LJ, Jones L, Garcea G, et al. Expression of thrombospondin-1 in resected colorectal liver metastases predicts poor prognosis. Clin Cancer Res 2005;11: 6567-73.

40. Firlej V, Mathieu JR, Gilbert C, Lemonnier L, Nakhlé J, GallouKabani C, et al. Thrombospondin-1 triggers cell migration and development of advanced prostate tumors. Cancer Res 2011;71: 7649-58.

41. Maeda K, Nishiguchi Y, Kang SM, Yashiro M, Onoda N, Sawada T, et al. Expression of thrombospondin-1 inversely correlated with tumor vascularity and hematogenous metastasis in colon cancer. Oncol Rep 2001;8:763-6.

42. Hawighorst T, Oura H, Streit M, Janes L, Nguyen L, Brown LF, et al. Thrombospondin-1 selectively inhibits early-stage carcinogenesis and angiogenesis but not tumor lymphangiogenesis and lymphatic metastasis in transgenic mice. Oncogene 2002;21: 7945-56.

43. Doll JA, Reiher FK, Crawford SE, Pins MR, Campbell SC, Bouck NP. Thrombospondin-1, vascular endothelial growth factor and fibroblast growth factor-2 are key functional regulators of angiogenesis in the prostate. Prostate 2001:49:293-305.

44. Petraki CD, Gregorakis AK, Papanastasiou PA, Karavana VN, Luo LY, Diamandis EP. Immunohistochemical localization of human kallikreins 6, 10 and 13 in benign and malignant prostatic tissues. Prostate Cancer Prostatic Dis 2003;6:223-7.

45. van den Berg YW, Osanto S, Reitsma PH, Versteeg HH. The relationship between tissue factor and cancer progression: insights from bench and bedside. Blood 2012;119:924-32.

46. Lindholm PF, Lu Y, Adley BP, Vladislav T, Jovanovic B, Sivapurapu $\mathrm{N}$, et al. Role of monocyte-lineage cells in prostate cancer cell invasion and tissue factor expression. Prostate 2010;70:1672-82. 